\title{
Prof. Dr. K. Schilder over de Positie van Emigranten met betrekking tot bestaande Kerken
}

Inleiding.

De Vrijmaking in Nederland in de veerliger jaren pretendeert geen kerkbreuk, maar kerkherstel te zijn geweest. Zij was een Verwerpen van boven Schriftuurlijke dogmatische bindingen en een strijd voor het behoud van een waarlijk gereformeerle Kerkrecht. In de acte van Vrijmaking word de bereidheid uitgesproken "zo hast als men dit hebben kan gemeenschap te willen oefenen met allen, die in de enigheid der leer, welke naar Jen Woorde (jods is. met ons willen leven of gaan leven in een aangenomen of wederom aan te nemen kerkenordening. op dat Woord gegrend".

Vrijgemaakt gereformeerde immigranten brengen deze geestelijke waarden mee in hun nieuwe vaderland en willen deze behouden in het doen van een kerkelijke keuze. Wij gaan na wat hiervan in de praktijk na 1945 terecht kwam. Maar alvorens eelt oordeel te geven umtrent de keuze van immigraliten doen wij eerst cen greep uit het overvloedige materiaal, dat prot. dr. K. Schilder over de eenheid der kerk en de positie van emigranten naliet. In zijn grafzerk staan terecht de woorden uit het Johannesevangelie gegiift: Dat zij allen één zijn. llet onderricht van Schilder over de eenheid der kerk.

Ten aanzien van kerken net dezelfds belijdenis heeft Schilder zich vóór de oorlog vooral uitgesproken over de verhouding van de Ciereformeerde Kerken mel de Christelijke (jereformeerde Kerk in Nederland.' Het voornaamste punt van verschil tussen deze kerkverbanden was niet de grondslag, maar de geschiedenis, nl. of de vereniging van Afgescheidenen en Dolerenden in 1892 naar de Schrift geboden of verboden was. Schilder betoogde het eerste, de Chr. Ger. het tweede.

Maar Schilder betoogde nog meer: "Ik zal niet eens eisen, dat een ander mijn kijk op de historie deelt. zal hij met mij in één kerk leven. Ik eis alleen, dat we aan heide zijden de belijuenis handhaven. Het eerste negatieve gezichtspunt brengt mee, dat ik niet kwaad word. als de anderen mij sectarier noemen, evenals ik het hèn doe; want als we bij elkaar komen, kunnen we later over dat interpreteren van historische data wel cen academisch debat in allerlei rust en vrede heginnen. En het tweede, positieve. gezichtspunt brengt mee. dat ik tenminste ai den grondslag en den scherpen prikkel tot herenging kan laten hlijven gelden"."

"Indien ik weiger het Wonrd te doen op den achtergrond treden terwille van menselijke cigengereidheidjes. al heten ze ook "religieus" 
(religie zonder band aan het gebod is inmers afgoderij. een monster!) cn als ik op het in het uur van scheiding en isereniging "fijne puntje" van de actuele gehoorzaamheid in het kerkelijke blijt vasthouden aan de onderscheiding der belijdenis: er is een kerk en daaroniheen vormen zich sectes (welk woord, ik herhial het, nieis hatelijks hoeft te hebben. alleen een wetstaxatie-oordeel geeft over ' $t$ verloop van historische processen in het licht van ' $t$ objectief gebod omtrent de kerkformaties), dan haat ik niemand, heb echter het grote voordeel. dat ik het objectieve gebod gehandhaafd heb. en DAN heb ik den steeds werkzamen prikkel tot hereniging vastgehouden. Want de Koning der kerk blijkt dan géén genoegen te nemen met het feit. dat op denzelfden 7.ondag. b.v. in Middelharnis twee dominees voor Cod onder ede retuigen. dat HIN PERSOONI.IJK toor Hem opgedragen is te doen wat in het formulier als taak van 's Koningswege omschreven staat . . Voor de "Kerken" zou er al veel gewonnen zijn. als ze alle met ernst en met nallwgezelte historiestucie zich voor de vraag plaatsen: zijn we Kerk. of ecte? Dat is niet alleen een kwestic van belijdenis, doch ook van lev'en, en daardoor van historie".

"Christus verdeelt zijn mandaat (gelijk dit onschreven is in de bevestigingsformulieren. die bij de Geref. Kerken en de Chr. Geref. Kerk letterlijk overeenstenmen) niet tegelijkertijd in één stad of dorp over verschillende kerken" "

"De successie-oorlog is geen private liefhebberij. maar het ahc der kerk"."

"Als men het kerk-instituteri-maken volstrekt vrij geeft. dan heeft men de eenheid der kerk als Gorls gehod losgelaten, die verbrokkeling gesanctioneerd. En dan heeft men eigenlijk - en daar komt het op ian. tegelijk de geretormeerde relijdenis omtrent de kerk losgelaten: dat ieder schuldig is, zich bij de ware kerk te voegen. Met una-sanctaonzichtbaarheden heeft dit "zich roegen" natuurlijk niets uit te staan"."

"Hierom is het hoog tijd, dai de kerken den eis "onderzoekt uzelf nauw" nu eens niet langer reserveren voor een toepassing in cen preek. die allcen individuen onder het ontlecumes neemt. Laat de instituten zich nauw onderzoeken" :

"Of er niet narigheid komen zal, indien wij verenigen? lk schreef voor enkele weken reeds: vast en zeker. Het zal tientallen jaren duren. ser wij den vrede hebben. en eindelijk eens rijp worden voor het hehandelen van he'use kwesties. indien we met elkaar gaan samenwonen. Maar lie kemende misere mag oms nict afschrikken. Zelfs de antipathie tegen het nublicke doen van bepaaide personen mag ons niet verhinderer. De kerk is er om narigheden van personen te !:enezen door hel Woord, en in gezonde sameleving... De zaak van de kerkelijke zonden in Nederlind heft houst".

"De kerk is er juist... on de "pluriforniteit" der natuur te rerlinderen. vanwege de zonde uiteen te vallen in pluraliteiten in rassenhaat. talen-uitsluiting, of van de separate stichting van telkens nieuwe mentaliteitsbarakken. klasse-societsiten. beschavingsclans ik kin geen kerk van nette. gezonde mensen. lk ken slechts de kerk van zulken. die in beginsel ziin gebracht tol leven en to eeuwige 
jeugd. maar dic voorts met duizend kwalen. duizend doden te strijden hebben. Ze moeten dat leren docir het Woord. Dait Woord wordt hun gebracht in en door . . . de kerk"."

"Indien, om maar bij Nederland te blijven, morgen dan den da! de Ned. Herv. Kerk, ook al zcu haar synode geen (welenschappelijk ingedacht) oordeel wille geven over 1834 en 1880, voor de toekorist zich zou willen vatsleggen op de gereformeerde belijdenis (en dus ook kerkregering), dan zouden we dadelijk moeten samenleven. Van de Nederlandse Chr. Ger. Kerk geld! hetzelfde tegenover de Geref. Kerken. Zoals tussen die kerk en haar afzonderlijke leden van den kant der kerk zelf de band nooit ontbonden mag worden (in de tucht) vanwege een eens begane zonde. doch aileen vanwege hardnekkigheid in de zonde. zo kan ook de ene kerk nooit van de andere harerzijds gescheiden willen blijven varwege een eens begane zondien, doch alleen van. wege hardnekkigheid in die zonde, vanwege het standvastig blijven bij wat verkeerd was, en het wederom voor eigen rekening nemen daarvan. Dit geldt te meer, omciat in het eerste geval (kerk tegenover individueel kerklid) het kerklid dezelfde bleef. terwijl in het tweede geval (kerk tegenover kerk) de groepen na 15 jaar. 100) jaar. enz. ten dele of algeheel verdwenen zijn. Van de Ved. Herv. Kerk van heden is niemand aansprakelijk voor de zonden van 18.34; de vraag is slechts. of de Hervornde zynode thans zou willen terugkeren tot de belijdenis. Van de in een tot leertucht besluitende synode aanwezige leden zijn na enkele jaren reeds velen gestorven. emeritus gewordell, niet meer gredeputeerd. Bovendien bestaat die synode niet meer .... : niet de hundelingen van eertijds, doch de houding van heden beslist. Tot de goede houding over en weer nu behoort oiok het leven voor het Schriftwoord, dat de zoon niet zal dragen de ongerechtigheid der vaderen. Met elke volgende generatie moet men om Christus' wil willen spreken. teneinde de situasie opnieuw op te nemen ... Een secte is een secte: maar de kerk, die niet de secte wil oproepen tot bekering. wordt sectarisch: zij wil niet samenbinden. Eell schisma is een schisma: maar wie degenen loslaat, die hijzelf schismatiek noemt. wordt zelf schismatiek: hij wil niet samenbinden"."

In en na de verwoestende volkerenkrijus en Nederlandse kerkstrijd in de Tweede Wereldoorlog bleef Schilder dan deze opvatting trouw: "We hebben nog altijd dien eenvoudigen plicht te erkennen. volgens welken allen, die in éénzelfde belijdenis hun geloof uitdrukken. bij clkánder behoren. Ware het niet deze overtuiging geweest. die achter onze vroegere polemiek met $\mathrm{Ch}$ Geref. woordvoerders als drijveind motief gelegen heeft, ze ware. althans in dien onvang, nitimer opgczet ... We moeten ons steeds weer voor ogen houden, dat een kerk een vergadering van gelovigen is. niet van gelijkgezinde in wetenschuppelijke vraagstukken. Een zuivere taxatie van wat in 1892 gebeurd is gaat in den grond der zaak terug op wetenschappelijke vragen van Jogmatischen. kerkhistorischen en kerkrechtelijken aard. Het is duidelijk dat zulke viagen in bepaude omssandigheden wel degelijk voor onze conscientie kunnen komen te staan. en dan in een comcret 
heslissing door ons in onze qualiteit van belijders moeten worden beantwoord, voor zover in zulk een antwoord de geloofsbeslissing verantwoording wil geven. Want als men ons voor een keus plaatst van ja of neen zeggen, van hlijien of heengaan. dan moet de belijder, die aan de van (iod gestekle normen trouw wil blijven, soms zeer intensief "n dit zijn hoden met kwesties van wetenschappelijke aard zich bezig houden teneinde te komen tot een wel-overwogen geloofshandeling. Maar om die geloofshandeling is het dan uiteindelijk te doen. Niet om de bedrevenheid in de be:ıntwoording van allerlei theoretische vragen".."1

Gereformeerd-Oecumenische Symode 1946 en de Vrijmaking.

Omtrent de Ger. Oec. Synode van Grand Rapids 1946 is Schilder niet gelukkig gestemd. Toch blijft hij objectief in de beoordeling. Hij constateert. dat de $\mathrm{zg}$. Oecumentsche Synode in wezen Grosheide en Ridderbos afvalt, ${ }^{12}$ ondat deze vergadering uitsprak, dat zelfs indien de synode der Gereformeerde Kerken in Nederland (inzake haar beslissingen van 1944 enz.) verkeerd zou zijn, dit geen breuk zou rechtvaardigen. $^{13}$ Juist, zegt Schilder, maar de synodalen, niet de bezwaarden. hebben anders gchandeld door de kerkelijke weg als revolutie te bestempelen en de bezwaarden het advies te geven dan toch maar het kerkverband te verbreken; voorts door te schorsen en af te zetten ... "Hoe het zij: indien die uitspraak der zg. oecumenische synode iets waard is, wel. dan tebben de heren Ridderbos en Polman en Grosheide en al die anderen daar in Amerika een "geweldige" afstraffing gehad. E.n ook die hele symoxle: Bergschenhoek is buiten de deur gezet. En die classis daar in Zeeuwsch-Vlaanderen: geen geestelijke gemeenschap meer, en zc. Maar natuurlijk denken ze, dat het net precies andersom is. Dal menen de mensen der oecumenische synode zelf ook: ze kennen de feiten niet!"14

Anderzijds betoogt Schilder, Jat de zg. oecumenische synode Greijlanus en hem bijvalt in de uitspraak. "ingeval iemand overtuigd is, dat een synode een onverantwoordelijke lceruitspraak doet. is hij niet gerechtigd cen breuk te verJorzaken, tenzij hij alle mogelijkheden heeft uitgeput. die in de kerkenordening voorzien zijn voor het ver. krijgen van revisie en de kerk erbij blijft een standpunt te handhaven dat tegenovergesteld is aan zijn overtuiging omtrent de waardheid ".". Sihilder merki op: "Dat is precies wat onzerzijds gezegd is. Daarom zeiden wij: wacht met binden tot na den oorlog en laten we dan nog eens praten. L.aat ons de mogeiijk.heid. die de K.O. biedt. gehruiken

Maar de heren Ridderbos. Nauta. etc zeiden ... Uitvoeren en anders maur het kerkverhand verbreken: officieel geschrift der synode (commissie Riclderbos). Nu kunnen de heren wel disen alsof Ridderbos hier gelijk kreeg maar dat is eenvoudige dwaasheid. Hier kregen de collega's gelijk, dic hij in hoogmoed uitgeworpen heeft . . ."

De belangstelling van Schiluer voor de $7 \mathrm{~g}$. oecumenische synode blijkt hieruit, dat hij in de Rubriek Persschouw van De Reformatie het verslag van de Zuid-Afrikaanse deputaten volledig in het Afrikaans uil Die Kerkblud van 7 Maart 1947 overneemt. ${ }^{14}$ 
Ondanks dat is er een ernstig misverstand ontstaan ten aanzien van het oordeel van (irand-Rapids omtrent de kerkelijke moeilijkheden in Nederland. Op 2 November 1948 sprak immers de Nederlandse vrijgemaakte svnode uit. dat de in (irand-Rapids bijeen geweest zijnde afgevaardigden uit Amerika en Afrika door hun handelingen ten aanzien van die moeilijkheden de aan Schrift en belijdenis en K.O. getrouw gebleven Gereformeerde Kerken in Nederland lichtclijk en onverhoord veroordee!d hebben. ${ }^{T}$ Zowel (jreijdanus" als Schilder"" hadden zich tevoren in gelijke zin uitgesproken. nl. dat daar ten aan. zien van de geschiedenis der kerken onderscheiden uitspraken zijn gevallen. welke niet alleen in strijd met de waarheid zijn, doch ook het rechtsbesef wonden. In het verslag in De Reformatie van 28 Juni 1947 is in te tekst van (irand-Ranids echter het tegendeet te lezen. Dit luidt: "In verband met vraare A: "Gravamen is ingedien teen die beslissing van die sinode van 19155, sub 4. Die sinode het geoordeel dat die beslissinge in ooreenstenming met Skrif en Belydenis is. Was hierdie beslissing reg?" wens hirdie sinode die volgende historiese feite in herinnering te bring:

(a) Die Chr. (jer Kerk van Amerika het die konklusies van Utrecht. 1905 geratifiseer in sy besluit van 19()8.

(b) Nooit is enige Skrifuuurlike besware aan dic adres van die sinole gerig teen punt 4 nic.

(c) Die Suid-Afrikaanse kerke het nooit die besluite van 1905 offisieel aangeneem nie.

Die sinole sal aan die Geref. Kerke in Nalerland meld dat dit nie 'n antword op hierdie vraug $k a n$ gee nie. omdat die nodige tyd ontbreek om genoegsaam kennis te neem van die gravamen wat by die sinode in Nederland ingedien is en van die rapporte waartoe hierdie gravamen aanleiding gegee het. Verder meen die sinode dat hy hom moet beperk tot die formulering van in oordeel met betrekking tot die verklaring van die sinode van 1946, somder om op) die konkrete moeilikhede van die Geref. Kerke in die Nederlande in te gaan. sodat die konklusies van Utrecht soveel moontlik in die agtergrond gelaat moet word, veral waar hulle vervang is deur dic verklaring van 1946 ... Die kommissie het gevoel dat dit geen mandaat onfrang het om belang te stel in die hishoriese inkleding waarin die verklaring tot ons gekom het nie... I kommissie is eenstemnig dat die ..Verklaring v'an 1946" in ooreenstemming is met Skrif en Konfessies. Ons beveel aan dat die sinode hierdie oord:el sy eie maak. Die sinode het hierdie rapport aanvaar". ${ }^{n}$

De conclusie hieruit kan naar mijn oordeel slechts zijn, dat de "synode" Grand-Rapids 1946 een theologisch wetenschappelijk oordeel heeft uitgesproken over het doghinatische gedeelto van de Vervangingsformule van 1946 zonder acht te slaun op do voorgeschiedenis walke aanleiding tot de scheuring in Nederland wa: Dus over deze formule zonder kop en zonder staart.

Naar het inzicht van Schilder was ook dit uitsluitend leerstellige nordeel onjuist: "Het eerste convent in Cirand-Rapids heeft al de verlangingsformule van 1946 gesanctioneerd als schriftgetrouw. Wij ver- 
werpen het stuk. Had men ons zo graag willen hebben, waarom heeft men dan hii voorbat zich laten opwarmen door de Amsterdamse vrienden. om ons vast te laten afwijzen?.. Wat heeft de kerkelijke hoogmoed der drijvers van "44 och een ellende gesticht. ook "Oecumenisch"."1

\section{Die Ciereformeerde Kerk in Suid-Afrika en de Vriimaking.}

Welke was nu het standpunt van de afgevaardigden van die kerk in hun rapport over deze zaak aan hun synode in Potchefstroom 1949? Daarin staat de volgende belangrijke noot te lezen: " $U$ deputute wil ser vorkoming van misverstand daarop wis dat die besluit van die sinode geen uitspraak doen! ox die vraag of so 'n verklaring as dié lan 1946 nodig en wenslik was nie, ook nie or die vraag of daar nie 'n heter verklaring gemaak $k o n$ word nie. Die sinode het eenvoudig verklaar dat die aan hom voorgelegde stuk in ooreenstemming met Skrif en Belydenis is". 22

Wat oordeelde de synode Potchefstroom nu over deza zaak? Op haar tafel lag niet alleen het verslag van haar afgevaardigden uit Cirand Rapids waarin de tekst van het dogmatische gedeelte van de Vervangingsformule 1946. dus zonder de historische inkleding en het bindend gezag daarvan in kop en staart, was opgenomen ${ }^{2}$, maar waarschijnlijk ook een brief van de Vrijgenlaakte Synode 1948:4 met cen mededeling omtrent de afwijzing van de uitnodiging deel te nemen aan een oecumenische synode in 1949 in Amsterdam te houden. welke afwijzing o.a. gegrond was op de opvatting dat Grand-Rapids 1946 onjuist over de historische situatie van de Vrijmaking in Nederland had geoordecld! ${ }^{-2-i}$

Op advies van de betrokken konımissia besluit de synode Potchefstroon 1949:

1. "dat die ekumeniese sinode "n adviserende karakter sal dra. in die sin dat dic besluite eers bindend sal wees nadat die betrokke nasionale sinode daaromtrent in besluit geneem het. ${ }^{26}$

2. (a) Kerklike moeilikhede in Nederland: Die eerw. Sinode neem met goedkeuring en waardering kennis van die optrede van die drie deputate in verband met hierdie saak.

(b) Die "Verklaring van 1446" word daardeur nie bindend vir die Cieref kerk in Suid-Afrika nie".:

Naar mijn oordeel volgt hieruit. dat de Synode Potchefstroom miet voldaan heeft aan de aanbiveling van (jrand-Rapids om de formule van 1946 als schriftgetrouw over te nemen. In de goedkeuring :n waardering voor het optreden van de órie deputaten ligt dit niet noodzakelijk opgesloten.

Dit laatste stelt nl. dr. (". van der Wat: "Aldus het synodebesluit van "1946" niet bindend voor Afriks. Maar wèl uitgesproken. die deze verklaring Schritıgetroun is. En daan mee is dus tevens gezegd. dat het verzet van die vrijgemaakten (en van de bezwaarden) tegen "1946" niet Schriftgetrous is . . . Dalarmee heeft Zuid-Afrika de Vriimaking afgewezen, daar deze zich juist verzet heeft tegen een Schriftuurlijk in hindend-verklaren van deze leer"."* 
Hier is mijns inziens sprake van een ernstige misvatting bij dr. Van der Waal, mogelijk wegens een gebrek aan toetsing van de Nederlandse vrijgemaakte uitspraak van 1948 en misschien ook geinspireerd door zijn opvatting dat dr. P. J. S. de Klerk zich blijkens zijn inaugurele reden van 26 Nov 1949 cen dankbaar leerling van dr. H. N. Ridderbos zou hebben betoond. Dit laatste kan geen argument zijn als men de waarschuwing van Schilder ter harte neemt te onderscheiden tussen het standpunt van de kerk en dat van particuliere theologen. Een optrcden van deputaten is nog iets anders dan een opvatting. Potchefstroom-1949 heeft het optreden van deputaten GrandRapids 1946, bestaunde in het zich distanciören ran kerkelijke moeilijkheden in Nederland, zoealgekeurd. Noch Cirand-Rapids, hoch Potchefstroom hebhen dus over de Vrijmaking als zodanig geoordeeld.

Men moge als Nederlands immigrant of oud-Nederlander met vrijgemaakt bloed liever gewenst hebben. dat ile synodocratie toen uitdrukkelijk was afgewezen in Zuid-Afrika: het is in ieder geval onjuist om uit het achterwege blijven daarvan af te leiden. dat de Vrijmaking is veroorleeld. Integendeel is de les der vrijmaking in Zuid-Afrika wel geleerd. doordat bij de herziening van die Kerkenorde door de Gereformeerde Kerk impliciet wèl het synodocratische, colleialistische stelsel is afgewezen." Dat blijkens het vorenstaande de synode Potchefstroom ondanks de aanwezigheid, van prof. dr. G. C. Berkhouwer - - eertjids voorzitter van de synode die Schilder schorste - haar eigen koers volgde in het geen uitspraak doen over de kerkelijke zaken in Nederland. is van grote betikenis voor het zelfstandige vordeel van Die Geref. Kerk in S.A

Maar ook al zou men met ir. Van dar Waal in het goedkeuren van het optreden van deputaten een aanvaarden van de juistheid van de dogmatiek van 1946 lezen. dan miste deze evenals 19(15 Nederland kerkelijke binding. De vrijmaking was een reactic geboden tegen de binding van 1942 waarin een gedeelte van $19(05$ eenzijdig werd herhaald. niet tegen de uitspraak als zodanig. waarover men nog wel praten wilde. $^{31} \mathrm{Nu}$ overigens in 1959 die formule door de synodalen in Nederland terzijdegesteld is:" noet men wel een summun aan verbeeldingskracht bezitten door te Jurven beweren dat zij in Zuid-Afrika nog zou gelden en worden gehandhaafd.

De reactie tegen de Vrimaking in de Amerikanse landen.

De ontwikkeling van de kerkelijke situatie in Amerika en Canada heeft Schilder met droefheid vervuld. In Augustus 1947 is hij op reis naar dit verre Westen en wordt zijn aandacht gevestigd op een publicatie van dr. R. J. Danhof als "ecretaris van de synodale Commissie" in The Bumner. dat het doel van zijn reis is Amerıka in te lichten over de kerkelijke strijd in Nelerland. Dr. Danhof. oud-leerling van de Vrije Universiteit, die ook in (jrand-R ıpid 1446 on Potchefstroom 1949 aanwezig was, waarschuwl. dat de Chr. Ref. Church de vrijgemaakte kerken niet erkennen. dat deze een nieuwe denominatie zijn waarmee geen correspondentie hestaat en dat de kerkeraden er dus goed dan zullen doen de consequentie te trekken en hem dus niet uit le nodigen om te spreken of te preken van hun kansels. 
Schilder wijst er op dat dit een officiöle kerkelijke uitlating is en dat in Nederland een predikant van de Chr. Ref. Church wèl in een vrijgemaakte kerk had gepreekt Het was voor Schilder een verkwikking reeds binnen 24 uur na aankomst in New York o.a. met lwee predikanten van de $\mathrm{Chr}$. Ref. Church over deze zaken te kunnen spreken en te concluderen, dat de Nedcrlandse synodocratie in Amerika misschien wel helpers, maar gecn discipels kon vinden. ${ }^{32}$ Op 5 September 1947 kriigt Grand-Rapicis dan een kans. die Zuid-Afrika heeft gemist. nl. dat Schilder in een publieke vergadering waar vele leden vitn de Chr. Ref. Church aanwezig waren. waaronder docenten en predikanten, voorlichting geeft over de "goddelijke waarheden" van de leeruitspraak van 1942. bevestigd in 1946. dic als zij inderdaad goddelijke watarheden zijn ook voor Amerikaanse gelovigen zullen gelden. ${ }^{33}$

In zijn adviezen aan emigr inten geeft Schilder de raad zich niet bij de Chr. Ref. Church te voegen. maar bij de Prot. Ref. Churches. Die kerken "zijn heel gewoon gereformeerd. Ze hebben de drie formulieren van enigheid. Verder nicts. Ze hebben de kerkenordening van ons. En ze hebben nog nooit iemand uitgeworpen: ze doen dat daar niet zo vlot als in de door dr. H.H K. opgejaagde kringen. Ze hebben dus geen conlessionele extrd-belasting uit tuchtuitspraken of leerformuletjes-ter-bescherming-van-gangbare-ideetjes. Wat wil men nog meer?"34 )p Schilders adviezen aan immigranten in het algeneen komen we nog terug.

Als er volgens latere berichien van immigranten in de Prot. Ref. Churches een bovenschriftuurlijke binding op komst schijnt te zijn. ${ }^{3.3}$ waarschuwt Schilder on heel rustig te wachten op wat de synode der Prot. Ref. Churches zal antwoorden op wat door onze eigen deputaten in opdracht onzer eigen svnode geschreven is en om niet af te gaan op persartikeltjes. ${ }^{36}$

Het blijkı echter, dat Schilder te optinistisch was. want tegen zijn verwachting in en ondanks zijn uilvoerige tegen-armumentatie in een reeks Reformatie-artikelen " (later gebundeld tot een brochure Boienschrifunurliike hinding, een nieuw gevaur), wordt deze nieuwe leer bindend ingevoerd. Maar zelfs nangende deze zaak bij de synode in Amerika zegt Schilder nog: "meldt u bij de Prot. Ref. Churches, maar laat meteen duidelijk weten. dat en waarom ge er niet aan denken kunt. bepaalde uitspraken te aanvaaiden .. Want we blijven nog van mening, dat we het aantal kerken in een bepaald gebied niet mogen vermeerderen door eigen schuld. Noch door de schuld van: zich niets van het bestaande aantrekken. Noch door de schuld van: onnodige bindingen onleggen. Noch door de schuld van: toegeven aun uitiliteitsoverwegingen, die we afwogen onder suhjectivistischen gezichtshoek"."

$\mathrm{Na}$ het vallen van de besliscing was Schilder opnieuw eerlijk en consequent. Hii schiff: "Wat de laatste weken gebeurd is in de Prot. Ref. Churches geeft me aanleiding tot de volgende opmerkingen:

(a) ik heb nog geen ogenhlik spijt gchad van wat ik in het verleden ten aanzien vall deze Prot. Ref. Churches heh geschreven en gedaan en gepleit. en geloof nog. dat het goed geweest is. 
(b) Maar nti ze laar het roer hebben ongeworpen. tegen alle broederlijke raadgevingen en theologische argumentatie in, aanvaard $k$ de consequentic van deze hun koerswijzıging, en acht het nu niet verantwoord, nog langer het woord terug to houden. dat als het enige thans nog rest: Jie kous is af, we zetten er een streep onder, en nemen afscheid. Met een gevoel van spijl. Maar toch zeer beslist ... En dus, de kous is af. We moeten maar alleen blijven profeteren. We willen wel vragen, we zullen niar bedelen. We willen niet de schuld hebben van een nieuw kerkje, liunmer zoveel. We zullen echter niet. als we dwaze binding afwijzen. de conseyuentie van zulke gehoor:aumheid beschouwen als zonde naar art. 79-81) K.O. We zullen zeggen: Kop op, de Leider Jer geschiedenis is God. Wie zich isoleert. is ditmaal - voor het eersi helaws in zijn mooie leven - - onze vriend Hoeksema. Van hem nemen we afscheid -.. niel als goed vriend, wel als "engel" der ontvangende kerk, die emigranten omvangt met zachte en in hun omhelzing beheerste armen"."

De leerbesluiten van de Prot. Ref. (hurches waren aanleiding 101 de stichting van de Canadian Ref. Churches, vooral bestaande uit vrijgemaakte Nederlandse immigranten. Deze stichting was op grond van deze binding gehoden." $\mathrm{Zij}$ traden in correspondentic met de Vrijgemaakte Kerken in Nederlaid, soch aanvaardiden deze door Nederland aangebodeit correspondentic niet ongewijzigd. doch wor zover binnen het raam van het kerkelijk leven uitvocrbaar en gewenst.": Daaruit blijk!, dat zij een zelfstandig kerkverband lo: van Nederland zijn. Begin 1964 bestond dit verband uit 23 gemeenten met 18 predikanten en in totaal ongeveer 6.200 ) leden.

We slaan nu een heel stuk geschiedenis over.

De vrijgematakte Nederlandse sinole van Rolterdam-Delfshaven 1964/1965 weigerde correspondentie met die (iercformeerde Kerk in Suid-Afrika en met de Chr. Ref. Church. ondat reeds in de correspondentie met de synodale Neterlandse kerken een onoverkomelijk bezwaar ligt de verbroken banden weer aan te knopen. Ds. I.. Selles van een Can. Ref. Church merkt hieromtrent op: "Met de Synode zien we deze dingen, en het is goed als ze klaar en duidelijk worden naar voren gebracht. Wel vraig ik me af of het niet beter ware geweest indien de Synode de Chr. Ref. (hurch en Dic Cicref. Kerk van Suid-Afrika voor de vraag had gesteld hoe zij bij deze stand van zaken een eventueel samengaan in correspondentiegenieenschap met de Geref. Kerken meent te kunnen combineren met haar gencenschap met de gebonden kerken. $\mathrm{Er}$ is ook nog zo iets als een uit de tent iokken van de ander, waar te meer reden voor is als die ander na twintig jaar niets van zich te laten merken. einclelijk zijn neus laat zien. lk ben bang dat met dit antwoord die neus wel weer eens binnen het tentdoek zou kunnen verdwijnen en lat er na al die jaren van het zo broodnodige gesprek en verantwoording nog weer niets komt. En dan zich maar troosten met de gedachte dat het de ander zijn schuld is. Wat een versclurikkelijke schrale troost is. Ik hoop maar dat ik me helemaal vergis met m'n vrees. en dat in plats van het "naar I'we tenten o Israel", het toch nog mag worden: "uit Uwe 
tenten, o Israel". Moet het dan eerst vechten wezen met elkadr, dat kan geen kwaad als dat in de wapenrusting Gods gebeurt. Misschien mag het zo komen tot het samen optrekken me! elkaar. God der heirscharen is nog altijd 's Heren naan".".

De synode van de Can. Ref. Churches. EJmonton. art. 74 besloot ondanks het Nederlandse besluit om deputalen te benoemen tot samenspreking met de Chr. Ref. Church. In het besluit daartoe wordt er op gewezen, dat beide kerkverbanden dezelfde belijdenisgescriften bezillen. maar de Chr. Ref. Church bovendien de conclusies van 19(15/ 10()8. de drie punten van Kalamazoo 1924 en een officiele uitlegging Jarrvan 1959/1960. een nieuwe kerkorde en correspondentie met de synodaal gersformeerde kerken in Nederland." Over al deze verschillen moet gesproken worden

Gevolg van dil canadees vrijgemaakte standeunt is kennelijk. dat de vrijgenlaakte Nederlandse synole Amersfoori-West 1967 de deur voor het gesprek met de Chr. Ref. Church weer geopend heeft." is teleurstellend en onbegripelijk. dal dezelfde synode van Amersfoort in hetzelfue besluit ten aanzien van Die (ieref. Kerk in Suid-Afrika niets is gevorderd. ondanks de omstandigheid. dat het enige verschilpunt met die kerk het bestaan van correspondentie met de Nederlandse ynodale kerken is. Dit blijkt op een meten met twee maten. te meer daar wegens de arbeid van vrigemaakt Nederlandse zendelingen in Zuid-Afrika met medewerking van die kork een gesprek toch bijzonder nuttig had kunnen zijn.

\section{Schilder over Afrikaunse persumingen.}

Deze zijn sporadisch en dateren voor zover mij bekend slechts uit het jaar 1946. Schilder heeft de indruk. dat de Zuid-Afrikaanse pers de synodocraten napraat en onder invloed van de V.U. staat. Omtrent het ratificatierecht van art. $31 \mathrm{~K}$.O. verwijst hij ds. J. V. Coetzee naar Ferste en Tweede Ilands Gezag, naar prof Deddens inaugurele rede en naar prof. (Greyndanus' kerkrechtelijke publicatie. ${ }^{40}$

Prof. Du Toit (/uid-Afrika) schriff: ...A; iemand in die Vrygemaakle Geref. Kerk teenoor sy sinode dieselfde housing sou inneem as prof. Schilder leenoor dié van die Geref. Kerke. sou dit spoedig tol kerkontbinding lei. As elkeen maar vir honself kan uitmaak of hy hom gaan onderwerp aan besluite al dan nie. is die deur vir anargie wyd oopgenrak." Tol zover Du Tcit.

Met het 2e zinnetje zijn we het helemaal eens. Maar daarom is let eerste ook onzin. Schrijver weet van de eigenlijhe toedracht niets af. Ilij geeft "harikatumr"."

Ook heeft Schilder zich teleurgesteld getoond over de publicatie in Die Kerkblesl van een artikel van de amerikadanse hoogleraar Bouma over de herkstrijd in Nederland. dat z.i. door een door oneerlijk was ell een zuiver extract van de onzuivere geschriften in gesprekken van V.l'. professoren. Hli vond het jammer. Jat na hei protest van ds. P. (i. W. Snyman op 27 Septemiser 1946 da correspondentie werd afgesloten. onulat de toon van deze predikant niet gedeugd zou hebben." 
Over Die Ciereformeerde Kerk in Suid-Afrika als zolanig heeft Schilder zich nooit witdrukkelijk litgesproken en evenmin over de vraug of het stichten van Vrye Gereformeerde Kerke wetrig was. Dit laatste heeft zelfs de vrijgemaakte synode in Kampen 1951 art. 138 in het midden gelaten.

Men mag de persoonlijke contacten met anti-vrijgemaakten betreuren - zo de opmerking van dr. R. J. Danhof op de synode Potchefstroom 155 Handelinge blz. 390 "Op meer as een plek het die kerklike onenighede in Nederland in Kanada 'n vrugbare teelaarde gevind" - de zaak van de correspondentie met de synodale kerken schijnt het "schibboleth" te zijn geweest voor het al of nie toetrecien tot die Geref. Kerk in Suid-Af,ika. In dit verband zijn de adviezen aan emigranten, die Schilder gaf van de grootste betekenis. Schilders adviezen an Nederlandse iripgemaakte emigranten.

Schilder heeft bijzondere zory voor de positie van emigranten getoond. Naar aanleiding van een brief uit Canada, waarin kerkelijke en maatschappelijke moeiten van vrijgemaakte immigranten worden weergegeven. volgt het advies: "Ik persoonlijk herhad, dat m.i. de Protestant Reformed Churches de enige zijn, waar onze kerkleden dadelijk thuis kunnen zijn; de Chr. Ref. Church heeft zich plomp verloren aan dic synodociaten uitgeleverd en hun verderfelijke formules plus andere ellenden aanvaard. En waar onze mensen. in feite van elkaar gescheiden worden. hoop ik. dat zij zich op ijjd zullen wapenen tegen de gevaren van het isolement, en - hoe dan ook -zullen trachten te komen tot contact met de Prot. Ref. Churches." " Een eis voor kerkelijke correspondentie inet vrijgemaakte kerken in Nederland voor aansluiting door immigranten in het land van hun vestiging met de kerken aldaar, stelt Schilder dus nie Ook K. C. van Spronsen (Rudolf van Reest) gceft ditzelfde advies."."

In Juli 1949 spreekte Schilder zich bijzonder duidelijk uit over de kerkelijke keuze van vrijgem:łakte imnigranten."1 lk citeer daarliit. Waarbij ik de toepassing voor Zuid-Afrika maak. Dit doe ik met te meer vrijmoedigheil. omdat Schilder. die zijn uitgangspunt vindt in het Amerikaanse kerkelijke leven. waar hij persoonlijke contacten had, toch ook aan het land van de Goede Hoop denkt. als hij op 30 Juli 1949 verzucht: Wat wèten wij eigelijk van Amerika en Zurid-Afrika?

Schilder wijst op de moeiten van emigranten, die zich in het land van hun keuze gaan vestigen en trouw willen blijven aan hun gereformeerde opvoeding, waartoe ook de les der Vrijmaking behoort. Zij hebben reeds de gewone moeiten van de aanpassing met het volk waarvan zij en vooral hun nageslacht deel gaan uitmaken. In de ontmoeting van de Nederlandse virijgemaakte immigrant met de gereformeerde Afrikaner bestaat er de volgende mogelijkhcid van kortsluiting: Nederlandse immigranten. vooral de oudere, zijn meestal personen met een bewogen verleden. $\mathrm{Zij}$ hebben de oorlog meegemaakt en moesten iegen de duivelse machten van de Hitlerbenden stand houden. Zij hebben de goede strijd gestreden tegen de hierarchie in de veertiger jaren, zagen na de oorlog de afbraak van het Nelerlandse imperium. 
het verval van het nationale en gereformeerde leven, ook in het hoger onderwijs. Zij maakten de gewone moeiten van emigratie mee met het verlies van vele vriendschapskerkelijke en familiebanden. terwijl vele relaties van hen inet hun niet in dank afnemen. dat zij juist naar het om de onderdrukking van de niet-blanken (ten onrechte) zo beruchte Zuid-Afrika vertrekken, dat de wereld tart. En daar willen zij hun positieve gereformeerde waarden, waaronder vruchten der Vrijmaking, niet verliezen.

Hij komt nu in de wereld van de Afrikaner. En wat is de Afrikaner? Hij is meer in ziclizelf gekeerd dan de Nederlander en vecht voor zijn blote bestaan sedert de dagen van de Oost-Indische (ompagnic. Hij vecht ook nu nog tegen da wereldopinie en voelt zich bedreigd door zijn vijandeı. maar weet ook dat hij leeft in het land van de Goede Hoop Darr woont hij samen met Engelsen en niet-blanken. Hij heeft geleerd in de geschielenis zich met zijn eigen zaken te bemoeien en illeen zijn eigen huishouding te doen. Zijn land is een land van uitersten. dorre droogien en watersnoden. een veeleisende natuur en ontzaglijke ruimten. Hij heeft niet alleen geleerd on te strijcler. maar sok on te aanvaarden en te berusten. Door zijn eigen zorgen voor de niet-blanken, ook op geestelijke gebied, o.a. in het zendingswerk, heeft hij van nature geen behoefte en nauwelijks tijd om de geschiedenis van buitenlandse kerken te bestuderen. waartoe de groie afstand op zichzelf al een belemmering oplevert.

Het omgekeerde geldt trouwens ook voor Nederlanders. Wat weten zij van de interne kerkelijke zaken van Zuid-Afrika af? De afscheiding van 1859 in Zisid-Afrika toont veel trekken van overeenkomst met die van 1834 in Nederland, maar eerst na vele jaren heeft men dit ontdekt.

In deze sfeer vindt de ontmoeting plitats. Wat is dan begrijpelijker dan dat de harmonie niet terstond gevonden kan worden. Toch zijn deze omstandigheden niet normatief voor het kerkvergaderend werk des Heren en geen grond voor rigen kerkstichting. Schilder heeft dit heel duidelijk gezegd: "Var, afzonderlijke instituering op basis van het vroegere lidmaatschap van een nederlandss. "vrijgemaakte" kerk kan niets komen. Primo: ondat een feit uit het verleden nimmer basis is voor kerkformatie. Ook dus het onrecht niet door vrijgemaakten in Nederland ondervonden. Secundo: omdat. waar dit de belijdenis moet zijn. meteen het kerkicerhand moet optrelen wil men althans voor zijn kinderen en kleinkinderen naar vermogen de bezwaren helpen bezweren, die het leven in Canada of Noord-Amerika oplevert voor de belijders van den Cisristus. Men moet maar eens hebben gezien hoevelen er ondergegaan zijn "in de geslachten".

De gemeenschappelijke belijdenis moet volgens Schilder dus grondslag voor de beslissing zijn. waar men zich nivet aansluiten. En dus ook van kerkorde. die op de belıjdenis berust. Aan een afzonderlijke kerk zonder kerkverband acht Schilder dus gevaar verbonden. Voor een uiterst zwak kerkverband in een uitgestrckt land geldt hetzelfde. Men denke slechts aan verandering van werk. soms gedwongen. met 
overplaatsing naar een omgeving. waar geen kerk is. Welke emigrant heeft de zekerheid, dat in zijn toekomstige standplaats of werkplaats een vrijgemaakte ker'k is?

"Tertio: omdat zulke plannetjes van "eigen" instituering in verreweg de meeste gevallen stuiten op het feit van het eenzaan wonen. op uren afstand van een ander, die ook hetzelfde geloof deelachtig is" (Schilder). De Gereformeerde Emigratiestichting heeft zich dit ter harte genomen door emigratie alleen aan te bevelen naar plaatsen waar gereformeerd kerkelijk leven mogelijk is. Canada. waar alleen al om de taal afzonderlijke instituering gewenst was. is daar een goed vooi: heeld van. Zelfs in een woonstreek als groot-Kaapstad wonen de leden van cle Vrye Kerk nog mijlen ver uiteen.

"Quarto: omdat instituering van een gemeente. die verband zou willen houden met andere geleijkgezinde gemeenten, alleen zin heeft. indien er vele van die zich kunnen vormen. wat. zie boven, uitgesloten is te achten" (Schilder). Die Gereformeerde Kerk in Kaapstad heeft als Afrikanervolk zelfs in het verleden met deze moeilijkheid getobt. omdat de "Doppers" hier maar dun gezaaill waren.

"Quinto: omdat het niet groed is. bij de komst in een bepaald land de historie. die dáár achter den rug is. te vergeten en net te doen alsof er nog nooit iets gebeurd is op het gebied van kerk. formatic en kerkverband. Indien daar al kerken zijn. op de basis der 3 formulieren, dan is daar al gewerkt donr Gods Geest, en moet niemand Hem in Zijn werk neseren" (Schilder). Dit is het meest indringede argument en men moet als Nederlands vrijgemaakt immigrant kennis nemen van de geschiedenis van het ontstaan van de Geref. Kerk hier in 1859. een boeiende realiteit van blijvende betekenis ook voor het heden en de toekomst.

Bij de beoordeling passe men voorts de wijze regel van art. 86 (vroeger 85 ) der K.O. toe. dat men in middelmatige dingen de buitenlandse kerken niet zal verwerpen, die een ander gebruik hebben dan wij. Schilder wijst voorts op persoonlijke meningsverschillen, die er met ambtsdragers kunnen bestaan: "Nu zegt iemand: ia maar. ge vindt in de kringen van Rev. Hoeksema in brochures en tijdschriften wel eens uitlatingen, die ons sterk herinneren aan wat we in die synodocratie hebben vernomen; en als onze emigrante met deze kerke zouden samenleven, dan zouden ze "ginds" weer kunnen beluisteren, wat ze hier hebben afgezworen. En dus - laat ze daar verre van blijven, tenminste, totdat alle theologische vraagstukhen. die met deze punten samenhangen, zijn opgelost in onzen zin. Hoe het dan tiot zolung moet met die emigranten, die hun avondmaalsgemeenschap, hun kinderdoop, hun vaste contact met anciere gelovigen, dat zijn vragen waarop het antwoord dan mermalen voorlopig achterwege blijft" Schilder wijst er op, dat in omgekeerde i ichting zich hetzelfde verschijnsel kan voordoen en stelt de vraag of het verstandig is tc zoeken naar uit. spraken van een persoon die in een kerkelijke samenleving optreedt en dan te denken dat men aan een bedenkelijke uitlating meent heel die kerk te kunnen leren kennen ... Men is zo wijs, zich te realiseren 
dat de kerken zelf pas kunnen geacht worden een bepaalde mening voor haar rekening te nemen, indien zij in een gerezen conflict officieel in geding gebracht is en ter afhandeling van dit conflict uitdrukkelijk is vastgelegd".

De Gereformeerde Kerk in Suid-Afrika heeft - zoals wij zagen - - in het conflict van 1942-1946 in Nederland nooit officieel een standpunt bepaald. Ook is noch van vrijgemaakte noch van synodale zijde vanuit Nederland ooit haar medewerking gevraagd tot oplossing of verzoening van de scheuring, hetgeen op grond van de bestaande correspondentieregeling denkbaar was geweest. In het bestek van dit opstel laten we de ontstaansgeschiedenis van de Vrye kerke rusten. hoewel zij uiteraard met het onderwerp nauw samenhangt.

\section{Schilder en Austrulië.}

Ook aan emigranten, die naar Australië vertrokken. heeft Schilder geen uitdrukkelijke adviezen omtrent een kerkelijke keuze gegeven. Wel vond ik van hem de volgende opmerking naar aanleiding van het advies van deputaten van de synodale kerken aan immigranten om zich bij de presbyteriaanse kerken te voegen: "Overigens: men ziet al weer: emigreren betekent heel vaak: de kinderen blootstellen aan gevaar. waarvan de ouderen zich voór het vertrek n:?uwelijks een denkbeeld kunnen vormen".: In Australië bestonden begin 1964 drie kerken gesticht door vrijgemaakte immigranten uit Nederland, bediend door arie predikanten met in totaal 1,019 leden. Men bedenke. dat de situatie in het angelsaksische Australie geheel anders is dan in Zuid. Atrika. waar taal-. godsdienst- en stamverwantschap op ruime schaal gevonden wordt.

Slot.

Als we het geheel van Schilders denken over de eenheid der kerk en zijn adviezen aan de emigranten samenvatten. moeten we helaas de gevolgtrekking maken. Jat ve!e Nederlandse immigranten in Zuid. Afrika zijn lessen niet ter harte genomen hebben. Schilder heeft inmers het institueren van afzonderlojke vrijgemaakte kerken anders dan in geval van zeer dringende noodzaak. $n l$. wegens beslissend verschil in belijulenis en kerkorde, afgekeurd.

Door toch tot afzonderlijke kerkstichting over te gaan en zich daarbij aan te sluiten is naar mijn overtuiging de ware eenheid der kerk niet op de juiste wijze ge7ocht. ook al verkeerden velen - bij wie ik mijzeld insluit - terzake in niet-schuldige onwetendheid. Het gevolg is nu, dat de lessen van de Vrijmaking slechts zeer ten dele tot nutte van de afrikaanse kerken zijn geweest en dat die vrye gereformeerde kerke door het gemis van een warkelijk functionerend kerkverband geen gereformee ide kerken. maar feitelijk independente kerken zijn geworden met alle gevaien van dien. wadronder gebrek aan geloofsgemeenschap met gereformeerde Afrikaners. Voorts verwarring ten opzichte van zendingvaagstukken en verlies van greep op de jeugd.

Hierom is er alles voor te zeggen. dat de Vrijgemaakte Kerken in Nederland opnieuu officieus of officieel contact of verband gaan zoeken 
met "Die Gereformeerde Kerk in Suid-Afrika", ook terwille van toekomstige gereformeerde emigranten naar de Republiek Zuid-Afrika.

De eenheid der plaatselijke kerken in Zuid-Afrika is verbroken door het stichten van vrije kerken door immigranten, die in Nederland voor het recht en de eenheid van de plaatsclijke kerk vochten. Is inet enkele feit, dat Die Gereformeerde Kerk in Silid-Afrika in roverwegend formele) correspondentie staat met synodiale kerken op meer (lan 10.000 kilometer afstand daarvoor voldoende grond? Ondanks ook mijn bezwaren tegen dit contact, lijkt mij genoemd standpunt kerkistisch.

Parow, K.P.

Dr. R. ROEI.EVEI.D.

November 1967.

(Dr. L. Roeleveld is reeds 'n genaturaliseerde burger van Suid-Afrika en juris van beroep. Afgesien van artikels in tydskrifte soos Lucerna, het van hom ook brosjures soos (jereformeerde Kerken in het privaatrecht (1958) verskyn. Sy deurleefde gereformeerde siening en wetenskaplike insig maak hom 'n waardevolle medewerker op teologiese gebied. Die skrywer het die redaksic meegedeel dat hy ook probeer om hierdie artikel in Nederlandse en vrygemaakte tydskrifte te publiseer. RED.)

\section{NOTEN:}

1. In het hiernavo!gende wordt geciteerd uit zijn Verzanielde Werken Afd. III De Kerk. Zijn bewogen oproep aan de Ned. Herv. Kerk om het beginsel der afscheiding van 1834 als juist te erkennen blifft buiten bespreking

2. Deel 1, blz 182 (19 Augustus 1932).

3. Blz. 183 (19 Augustus 1932).

4. Blz. 187 (16 September 1932).

5. Blz. 189 (16 September 1932).

6. Blz. 190 (16 September 1932).

7. B|z. 191 (16 September 1932).

8. Blz. 266 (30 Junı 1933).

9. Blz. 267.268 (30 Jun 1933)

10. Deel 2. blz. 415-414 (26 Mei 1939).

11. De Reformatie, 2 Febr. 1946.

12. De Reformatie, 23 Nov. 1946

13. Handelinge Gereí. Kerk S.A.. 1949, blz. 44 en De Reformatic. 28 Juni 1947.

14. De Reformatie, 23 Nov. 1948. blz. 59.

15. Zie noot 13 .

16. De Reformatis, 19 April, 26 Anril. 3 Mei. 10 Mei. 17 Mei. 31 Mei en 28 Juni 1947.

17. De Reformatic, 13 Nov. 1948.

18. De Reformatie, 14 Dec. 1946.

19 De Reformatie, 13 Nov. 1948 , blz 62.

20. Handelmge Geref. Kerk S.A., 1049. blz. 44-45.

21. De Retormatic, 30 Oct. 1948, b/z. 43.

22. De Reformatie, 28 Juni 1947.

23. De Reformatic, 28 Juni 1947 en Handelinge Gerek Kerk S.A. 1949. bly. 46 ev.

24. De Reformatie, 13 Nov. 1948. blz. 67; Handelinge Potchefstroom 1949 maken geen melding van die brief

25. In het voorgaande is reeds betoogd dat deze opvatting op misverstand berusite.

26. Handelinge 1949. blz $3(14$ 
27. Handelinge 1949, b!z. 323: ook vermeld dosr dr. C. van der Waal in De Reformatic van 16 Juni 1956. $\mathrm{Vgl}$. Schilder in De Reformatic van 13 Sept. 1947. Waarin hij erop wijst. dat de besluiten van een "occumenische synode" nog moeten geratificeerd worden door de landelijke kerken en niet zomaar binden.

28. De Reformatic. 16 Juni 1956. blz. 310.

29. Zie mijn hespreking van de "Handleiding by dic K.O." in Lucesna. 7e jrg.. blz. 69-75.

30. Zie mijn artikel in Dienst. Maandblad voor ouderlingen en diakenen. $13 \mathrm{e}$ jrg. 1964. blz. 153-171.

31. Over de zelfhandhaving in de vijze waarop deze lerzijdestelling geschiedde schreef ik in De Reformatic van \& Januiri 1960. Men mag deze houding echter Zuid-Afrika nict toereken:n!

32. De Reformatic, 13 Sept. 1947.

33. De Reformatic. 20 Sept. 1947.

24. De Reformatic. $16 \mathrm{Juli} 1949$.

35. De Raformatic. 4 Febr. 1950: zic ook 5 Augustus 1950.

36. De Reformatis, 11 Februari 1950)

37. De Reformatic. 9 Sent. 1950 beval het ontwerp leerbesluit; Zic ook 22 S.pt 1951.

38. De Reformatic. 28 October. 4. 11. 18. 25 November, 2 en 16 December 1950; 6. 13. 20. 27 .lanuari 1051: 3. 10. 17, 24 Fcbruari 1951. De dogmalische punten laat ik in dit opstal rusten.

39. De Reformatic. 16 Sept. 1950).

40. De Reformalie. 17 N'ov. 1951.

41. Voor een verantwoording van vicze stelling zic o.a. het getuigenis van de kerk van Chatham Ontoria. De Reformatic. I Dec. 1951.

42. De Reformatic, 22 Sent. 1951. Acta Nationale Sunods. Can. Ref. Churches a d 1954. gehouden te Carman. Manitoba. Nov. 1954, blz. 30-31.

43. Can Reformed Mag.. vol. 14, nr. 1 en 2.

44. Can. Reformed Mag. Christmas lssue 1965.

45. Gereformeerd Gizinsblad. 4 Sept 1967.

46. De Reformatic. 6 Juli 1946

47. De Reformatic, 7 Sept. 1946.

48. De Reformatic 14 December 1946.

49. De Reformatic. 12 Juni 1948.

50. De Reformatic, 12 Maart i949.

51. De Reformatie, 16. 2.3 en 30) Juli 1949.

52. De Reformatic. 28 April 1951. 